\title{
Evidence for spatial variability in estuarine food webs
}

\author{
Linda A. Deegan*, Robert H. Garritt \\ The Ecosystems Center, Marine Biological Laboratory, Woods Hole, Massachusetts 02543, USA
}

\begin{abstract}
The importance of phytoplankton, benthic microalgae, fresh and salt marsh emergent plants, and terrestrial organic matter to the estuarine food web of Plum Island Sound, Massachusetts, USA, was evaluated using the stable isotopes of carbon, nitrogen and sulfur. Three distinct regions of the estuary were examined: the oligohaline upper estuary with high freshwater inputs and fringing fresh marsh, the middle estuary with extensive salt marsh, and the lower estuary with a greater proportion of open bay and a direct connection to open ocean. In each region, sources of organic matter for pelagic and benthic aquatic consumers were compared with the range of organic matter sources available in the entire estuary. Consumers in all regions relied most heavily on locally produced organic matter. In the upper estuary, most consumers had $\delta^{13} \mathrm{C}$ values of -29 to $-21 \%$ and $\delta^{34} \mathrm{~S}$ values of about $8 \%$, which indicated dependence on a mixture of fresh marsh emergent vegetation and phytoplankton from the oligohaline region. In the middle and lower estuary, consumers had $\delta^{13} \mathrm{C}$ values of -23 to $-15 \%$ and $\delta^{34} \mathrm{~S}$ values of 5 to $15 \%$ resembling a mixture of Spartina spp., benthic microalgae and marine phytoplankton. Terrestrial organic matter was of minimal importance in the upper estuary and was not evident in the food webs of the middle and lower estuary. The isotopic values of pelagic consumers reflected a greater dependence on phytoplankton than those of benthic consumers, which were closer to fresh or salt marsh emergent vegetation and benthic microalgae. Several of the patterns revealed by examination of organic matter sources for the food web of the Plum Island Sound estuary have implications for our general understanding of estuarine food webs. First, while there is substantial spatial heterogeneity in organic matter sources within a single estuary, consumers tend to utilize sources of organic matter produced in the same region of the estuary in which they reside. Second, consumer dependence on terrestrially derived riverine organic matter is minimal, even in the relatively small region of the estuary where its availability is the highest. Third, benthic and pelagic organisms rely on different mixes of organic matter sources.
\end{abstract}

KEY WORDS: Stable isotope - Estuarine food web Higher trophic level Benthic Pelagic Invertebrate - Fish - Shellfish

\section{INTRODUCTION}

Despite years of research on the habitat use and feeding ecology of many abundant estuarine animals, we still do not know which plants form the base of food webs that support high levels of secondary productivity in estuaries. Terrestrially derived organic matter carried by rivers, high in situ phytoplankton or benthic microalgal production, and abundant biomass of marsh plants cycled through a detrital pathway all have been proposed to explain high production of estuarine consumers (Nixon et al. 1986, Day et al. 1989,

\footnotetext{
·E-mail: ldeegan@lupine.mbl.edu
}

Keller et al. 1990, Mallin \& Paerl 1994, Deegan et al 1995). Although hypothesized to be important (Hackney \& Haines 1980, Armstrong 1982, Ittekkot 1988) riverine particulate organic matter (POM) appears to be a small component of most estuarine food webs (Coffin et al. 1989, Fry et al. 1992a, Peterson et al. 1994). The importance of phytoplankton and benthic microalgae are indicated by their high palatability and the short, efficient nature of algae-based food webs leading to fish (Ryther 1969, Keller et al. 1990, Mallin \& Paerl 1994). The importance of material derived from emergent salt marsh vegetation is supported by direct evidence of detrital utilization by consumers (Tenore \& Hanson 1980, Tenore 1983, Couch 1989, Deegan et al. 
1990) and by calculations that indicate salt marsh vascular plant production must be included in total estuarine production to explain fish yields (Nixon 1988). Others have argued that because of energy losses associated with the detrital food chain, and the low quality of the material by the time it reaches the open water area of an estuary, emergent marsh and terrestrial inputs cannot be a great source of food support to fishes (Peterson \& Howarth 1987, Day et al. 1989).

The spatial complexity of estuaries, variations in water and organic matter exchange, and multiple potential organic matter sources all complicate the determination of the relative importance of organic matter sources that support estuarine consumers. Carbon, nitrogen and sulfur stable isotopes of organic matter have proven useful as tracers of organic matter for our understanding of food web structure in a variety of aquatic ecosystems. The use of stable isotopes to determine food web structure involves the comparison of stable isotope ratios between consumers and food resources and requires distinct differences in isotopic values among food resources. Early studies using just the stable carbon isotope were limited in their ability to differentiate organic matter sources because a mixture of terrestrial $\left(\delta^{13} \mathrm{C} \sim-27 \%\right)$ and salt marsh $\left(\delta^{13} \mathrm{C}\right.$ $\sim-13 \%$ organic matter yielded organic matter with a $\delta^{13} \mathrm{C}$ similar to marine phytoplankton $\left(\delta^{13} \mathrm{C} \sim-21 \%\right.$ ) (Peterson et al. 1980, Peterson \& Fry 1987, Michener \& Schell 1994)

Multiple stable isotope comparisons provide significantly more power to resolve food web structure than does a single isotope approach (Peterson et al. 1985). In estuaries, $\delta^{13} \mathrm{C}$ and $\delta^{34} \mathrm{~S}$ are most useful in the discrimination of phytoplankton from terrestrial, marsh and benthic algae (Fry \& Scherr 1984, Gearing 1988, Michener \& Schell 1994). For carbon, the $\delta^{13} \mathrm{C}$ range is generally widest among algae groups such as benthic microalgae, macroalgae and phytoplankton which fix carbon from a variable $\delta^{13} \mathrm{C}$ DIC (dissolved inorganic carbon) pool in the estuary (Maberly et al. 1992, Goerike et al. 1994, Lajtha \& Marshall 1994). Benthic microalgae tend to be more enriched in $\delta^{13} \mathrm{C}$ than phytoplankton because of boundary layer effects which cause reduced isotopic fractionation due to the greater diffusional resistance of $\mathrm{CO}_{2}$ or $\mathrm{HCO}_{3}{ }^{-}$in less turbulent environments (Maberly et al. 1992, France 1995a). Plants in terrestrial and marsh habitats are more tightly constrained because they fix atmospheric ${ }^{13} \mathrm{CO}_{2}$ (Lajtha \& Marshall 1994). In contrast, variability of $\delta^{34} \mathrm{~S}$ is highest among marsh plants ( $\delta^{34} \mathrm{~S}$ typically -10 to $+5 \%$ ) that derive sulfur from a more variable and usually light $\delta^{34} \mathrm{~S}$ inorganic sulfur pool in the sediments. Variability of $\delta^{34} \mathrm{~S}$ is lowest in macroalgae and phytoplankton $\left(\delta^{34} \mathrm{~S} \sim+18 \%\right)$ because they use seawater sulfate. $\delta^{34} \mathrm{~S}$ values for benthic microalgae are inter- mediate in range ( 4 to $14 \%$ ) depending upon the proportions of reduced sulfur and seawater sulfate at the sediment/water interface (Sullivan \& Moncreiff 1990 , Currin et al. 1995, Newell et al. 1995). Thus, stable sulfur and carbon isotopes may help differentiate benthic versus pelagic and vascular plant versus algal sources.

Dual isotope plots of $\delta^{15} \mathrm{~N}$ versus $\delta^{13} \mathrm{C}$ may be helpful in resolving marine versus terrestrial sources of organic matter (Fry \& Scherr 1984, France 1995b) and determining trophic level (Fry \& Scherr 1984). The naturally occurring range of $\delta^{15} \mathrm{~N}$ in plants is smaller than that of $\delta^{13} \mathrm{C}$ (Gearing 1988). Within estuaries the differences in $\delta^{15} \mathrm{~N}$ between primary producers are small (Fry \& Scherr 1984); however, terrestrial organic matter $(\sim 0 \pm 2 \%)$ is significantly lighter than estuarine organic matter (Fry \& Scherr 1984, Schoeninger \& DeNiro 1984, Michener \& Schell 1994). Shifts in isotope ratios associated with trophic fractionation must be accounted for when comparing the isotopic ratios of consumers to food sources (Peterson \& Fry 1987, Michener \& Schell 1994). $\delta^{13} \mathrm{C}$ and $\delta^{34} \mathrm{~S}$ undergo little further fractionation $(<1 \%$ per step) with food assimilation, while $\delta^{15} \mathrm{~N}$ changes are larger $(\sim 2$ to $4 \%$ per trophic step) and more variable (Minagawa \& Wada 1984, Peterson \& Fry 1987, Michener \& Schell 1994).

Our goal in this paper is to present a view of the spatial variation in use of organic matter sources in food webs of estuaries. Our hypothesis was that the isotopic composition of consumer organisms would reflect the locally produced organic matter. To test this hypothesis, we completed stable isotope $\left(\delta^{13} \mathrm{C}, \delta^{15} \mathrm{~N}\right.$, and $\left.\delta^{34} \mathrm{~S}\right)$ analysis of producer and consumer organisms in the upper, middle and lower estuary of Plum Island Sound.

\section{STUDY AREA}

The Plum Island Sound system, Massachusetts, USA (Fig. 1), is a productive riverine salt marsh estuary. The estuary has a vertically well-mixed water column and a horizontal salinity gradient that ranges from 0 to $32 \mathrm{ppt}$. The system has a mean tidal range of $2.6 \mathrm{~m}$ and mean depth of $1.6 \mathrm{~m}$ at mean low water. The Parker River contributes an average discharge of $\sim 1 \mathrm{~m}^{-3} \mathrm{~s}^{-1}$. The upper estuary is characterized by terrestrial inputs of DOM (dissolved organic matter) and POM, and is dominated by Typha latifolia and Scirpus americana tidal freshwater marshes with fringing Spartina alterniflora along the river banks. The middle estuary is a typical New England salt marsh consisting of $S$. alterniflora along the creek banks and Spartina patens in the high marsh, with productivities around 600 to $700 \mathrm{~g}$ dry wt $\mathrm{m}^{-2} \mathrm{yr}^{-1}$ (Montagna \& Ruber 1980) and extensive intertidal mud and sand flats. The lower estuary is an open bay with steep shores, sand flats and little salt marsh. 


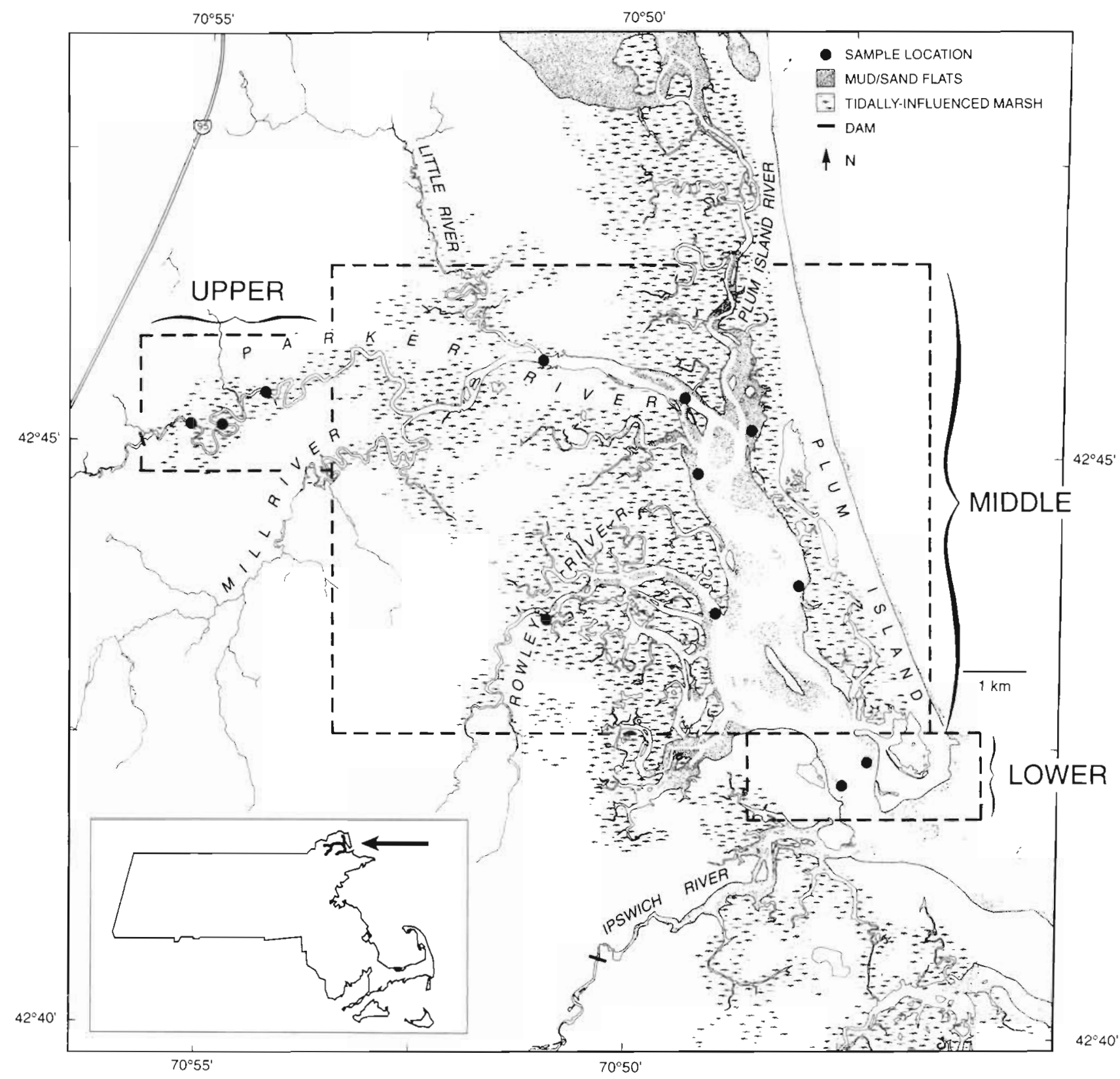

Fig. 1 Plum Island Sound estuary indicating upper, middle and lower regions. (-) Specific sampling locations. Insert shows region in northeastern Massachusetts, USA

Phytoplankton and nutrients have distinct seasonal cycles and show consistent patterns along the salinity gradient. Nitrate is higher at the freshwater end and lower at the marine end, while $\mathrm{NH}_{4}{ }^{+}$shows a pattern of regeneration in the middle estuary (Vorosmarty \& Loder 1994). Typical midsummer, middle estuary values for $\mathrm{NH}_{4}{ }^{+}$are 5 to $20 \mathrm{kM}$, while $\mathrm{NO}_{3}{ }^{-}$values are 1 to $10 \mu \mathrm{M}$. High phytoplankton biomass is present in the upper estuary in summer (Wright et al. 1987). During the summer, chlorophyll a concentrations in the upper estuary are often greater than $25 \mu \mathrm{g} c h l a 1^{-1}$. In the middle estuary, water column chl $a$ is relatively low $\left(<5 \mu \mathrm{g} \mathrm{chl} \mathrm{a} \mathrm{l}^{-1}\right)$ considering the levels of available nitrogen, but fairly typical when compared to estuaries of similar tidal range (Wright et al. 1987, Monbet 1992). Edaphic alga chl a values are low in the mudflats of the upper estuary (peak summer values of $-20 \mathrm{mg} \mathrm{chl}$ a $\mathrm{m}^{-2}$ ), high in mud-sand flats in the middle estuary $\left(\sim 70 \mathrm{mg} \mathrm{chl} \mathrm{a} \mathrm{m}^{-2}\right)$ and low again in the exposed sandy flats of the lower estuary $\left(\sim 20 \mathrm{mg} \mathrm{chl} \mathrm{a} \mathrm{m}^{-2}\right.$, authors' unpubl. data). Macroalgae, such as Ulva sp., Enteromorpha sp. and Cladophora sp., although present 
throughout the system, are incidental and appear to contribute little organic carbon to the system.

DOC (dissolved organic carbon) composition along the salinity gradient reflects the contribution of primary producers to the organic matter budgets. The riverine concentrations of DOC are high $(800 \mu \mathrm{M})$, while marine concentrations are low $(100 \mu \mathrm{M}$, Fry et al. 1992a). Based on stable isotope evidence, 2 withinestuary sources of DOC, one in the upper estuary from the oligohaline phytoplankton bloom and one in the middle estuary from a mixture of estuarine phytoplankton and Spartina spp., are important (Fry et al. 1992a, Peterson et al. 1994).

Fauna are abundant and diverse throughout the estuary. In all, 28 species of fish have been recorded in the lower and middle estuary and another 10 from the upper estuary (Jerome et al. 1968, Deegan unpubl. data). The zooplankton and benthic fauna are typical of shallow estuaries in the Gulf of Maine, USA (Jerome et al. 1968). The upper estuary has a mix of fish species representing freshwater, diadromous and estuarine life-histories. Estuarine species such as mummichogs Fundulus heteroclitus, Atlantic silversides Menidia menidia, winter flounder Pleuronectes americanus and bluefish Pomatomus saltatrix co-exist with typical freshwater species such as bluegill Lepomis macrochirus and white perch Morone americana. Many of these species are present as larvae and juveniles and grow rapidly during the summer months. As is typical of an upper estuary (Day et al. 1989), the benthic community is reduced in species richness compared to the lower or middle estuary and the bivalve community is absent (Jeffrey Hughes, Marine Biology Laboratory, Woods Hole, MA, pers. comm.). The dominant crustacean macrofauna are white-fingered mud crabs Rhithropanopeus harrisii, amphipods Gammarus tigrinus and sand shrimp Crangon septemspinosa. In the middle estuary, the fish community is dominated by estuarine species such as Atlantic silversides, mummichogs, winter flounder, three-spined sticklebacks Gasterosteus aculatus, blackspotted sticklebacks Gasterosteus wheatlandi and bluefish. The macrofaunal crustacean community is dominated by sand shrimp and green crabs Carcinus maenus. The conspicuous filter feeding bivalve species are ribbed mussels Modiolus demissus along the marsh banks, soft shell clams Mya arenaria in the tidal flats and oysters Crassotrea virginica in the river channel. In the lower estuary, the nearshore fish community is dominated by typical estuarine species such as Atlantic silversides and mummichogs, but also includes sizable populations of menhaden Brevoortia tyrannus, smelt Osmerus mordax, winter flounder and blackspotted sticklebacks. Sand shrimp and green crabs are again the dominant macrocrus- taceans. Blue mussels Mytilus edulis and soft shell clams are the prevalent bivalves.

\section{METHODS}

Sample collection and preparation. Samples for stable isotope analyses were collected during the summer (June to August) of 1993, with some additional summer collections in 1994 and 1995 in the middle reach of the estuary. Samples in the middle estuary were taken in 2 sub-regions: Mid1 - along the main stem of the Parker River; and Mid2-along the Rowley River. Data from these 2 sub-regions are presented separately in Table 1 ; however, preliminary examination of the data indicated no difference ( $p>0.05$ ) between these 2 subregions, and the data were combined under Middle in all analyses. Samples collected included sediments, water for seston, standing live marsh plants, invertebrates and fish. Sample preparation of all types of collections included isolating and cleaning the sample, washing with deionized water, drying $\left(60^{\circ} \mathrm{C}\right)$ and grinding to a powder with a Wig-L-Bug grinder (Crescent Dental, Lyons, IL). Sediment samples for $\delta^{13} \mathrm{C}$ and $\delta^{15} \mathrm{~N}$ were collected from the top $0.5 \mathrm{~cm}$, dried, pulverized, acidified with $1 \mathrm{~N} \mathrm{HCl}$, redried and ground. Water samples for seston $\mathrm{PO}^{15} \mathrm{~N}$ and $\mathrm{PO}^{13} \mathrm{C}$ (particulate organic ${ }^{15} \mathrm{~N}$ and ${ }^{13} \mathrm{C}$, respectively) analyses were vacuum filtered until clogged onto precombusted $\left(500^{\circ} \mathrm{C}\right) \mathrm{GF} / \mathrm{F}$ filters. Filters were acidified with several drops of $1 \mathrm{~N} \mathrm{HCl}$, dried, and stored in a desiccator. Green tissue of live plants was collected by hand. Plant samples were washed free of mud and debris and then dried. Ground plant tissue samples for $\delta^{34} \mathrm{~S}$ were rinsed in deionized water to remove seawater sulfate and redried. Zooplankton samples were collected using a plankton net (330 $\mu \mathrm{m}, 0.5 \mathrm{~m}$ diameter hoop). Zooplankton samples were initially resuspended in water collected from the respective station. Zooplankton were separated from phytoplankton and detritus by light migration and hand picking, then vacuum filtered onto precombusted $\left(500^{\circ} \mathrm{C}\right) \mathrm{GF} / \mathrm{F}$ filters and dried. Zooplankton samples for $\delta^{34} \mathrm{~S}$ were rinsed with deionized water during the filtering process. A $10 \mathrm{~m}$ beach seine ( $4.7 \mathrm{~mm}$ mesh) and a small boat with a $4.8 \mathrm{~m}$ trawl (15.8 $\mathrm{mm}$ net with $4.7 \mathrm{~mm}$ cod end mesh) were used for fish and crustacean collections. Other macrofauna were collected by hand. Fish used for stable isotope analysis were restricted to young of the year so that their tissue would most likely reflect recently acquired food sources. Macrofauna and fish tissue samples were dissected for muscle tissue. Ground animal tissue samples for $\delta^{34} \mathrm{~S}$ were rinsed in deionized water to remove seawater sulfate and redried. Animal $\delta^{13} \mathrm{C}$ tissue samples that were suspected to have car- 


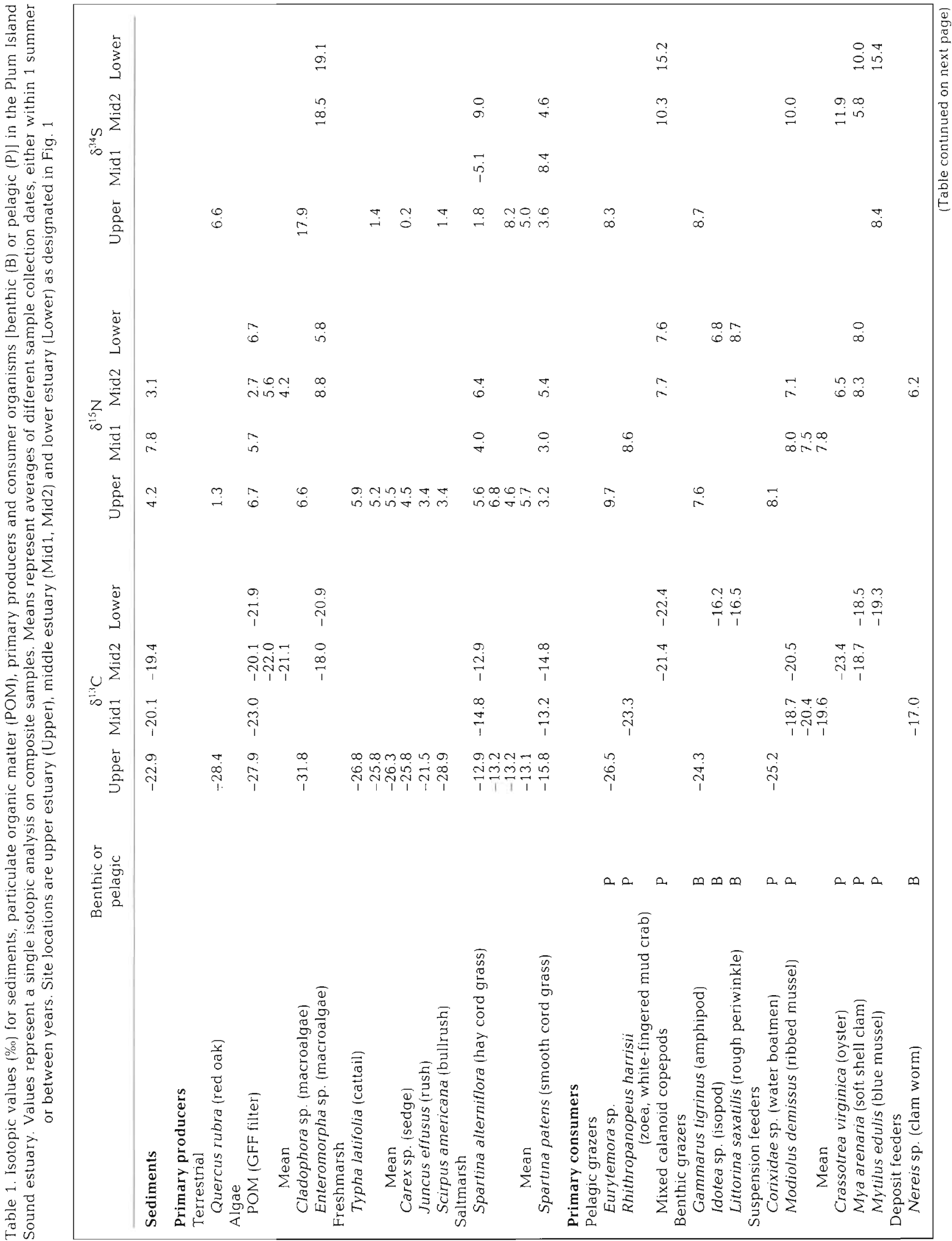




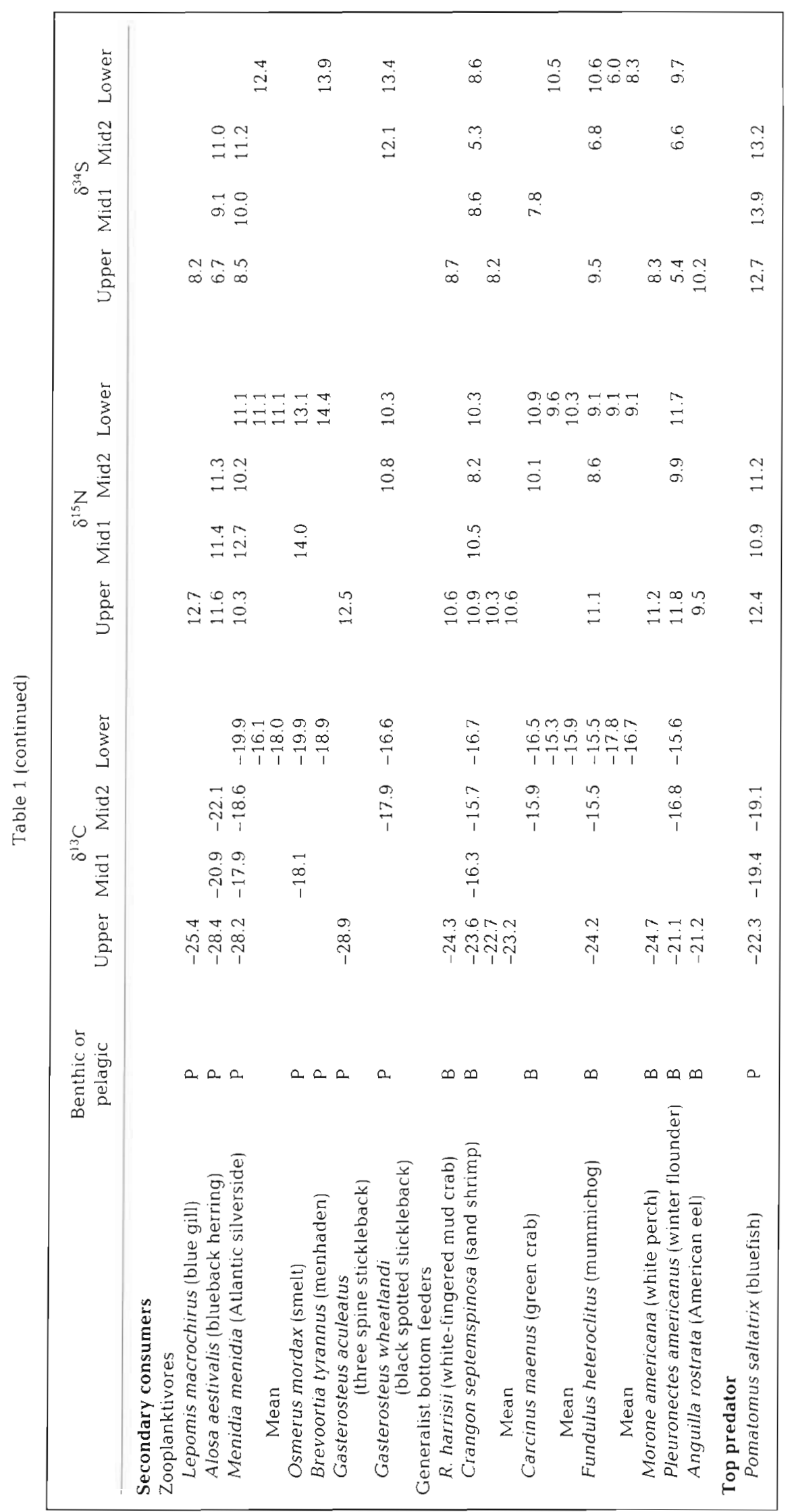


bonate contamination were acidified with $10 \% \mathrm{HCl}$ and redried.

Isotope measurements. Isotope analyses were conducted on pooled samples of the same species from a single collection date and site. Pooled samples provided an integrated population estimate of natural stable isotope abundance and enough material for sulfur isotope analyses. Occasionally replicate analyses were run on pooled individuals collected from the same site but at a different time.

Plant, animal, sediment, and POM samples for $\delta^{15} \mathrm{~N}$ and $\delta^{13} \mathrm{C}$ were analyzed using an automated elemental analyzer with a cryogenic purification system coupled to a Finnigan Delta $S$ isotope ratio mass spectrometer (Fry et al, 1992b). Plant and animal samples for $\delta^{34} \mathrm{~S}$ were analyzed on a Finnigan MAT 251 as $\mathrm{SO}_{2}$ using sealed tube combustion, $\mathrm{BaSO}_{4}$ precipitation and decomposition to $\mathrm{SO}_{2}$ (Dornblaser et al. 1994). All isotope analyses were performed at the Stable Isotope Laboratory, Marine Biological Laboratory, Woods Hole.

Stable isotope ratios are expressed in $\delta$ notation according to the following:

$$
\delta X(\%)=\left[\left(R_{\text {sample }} / R_{\text {standard }}\right)-1\right] \times 10^{3}
$$

where $X$ is ${ }^{13} \mathrm{C}$, ${ }^{34} \mathrm{~S}$, or ${ }^{15} \mathrm{~N}$ and $R$ is ${ }^{13} \mathrm{C}:{ }^{12} \mathrm{C},{ }^{34} \mathrm{~S}:{ }^{32} \mathrm{~S}$, or ${ }^{15} \mathrm{~N}:{ }^{14} \mathrm{~N}$. Standards are Peedee Belemnite for $\mathrm{C}$, Canyon Diablo triolites for $\mathrm{S}$, and air for N. Analytical precision was $\pm 0.1 \%$ for $\delta^{15} \mathrm{~N}$ and $\delta^{13} \mathrm{C}$, and $\pm 0.2 \%$ for $\delta^{34} \mathrm{~S}$.

Data analysis. The $\delta^{13} \mathrm{C}$ and $\delta^{34} \mathrm{~S}$ data were tested for differences between region (upper, middle and lower estuary) and feeding zone (benthic or pelagic, Table 1) using 2 -way ANOVA (Zar 1984). The $\delta^{15} \mathrm{~N}$ data were analyzed using region and trophic level (plant and primary, secondary or tertiary consumer) as main factors. All analyses included an interaction term, and significance level was $\alpha=0.01$. Tukey's procedure was used to test for differences in mean values. To prevent overrepresentation of a single species in the ANOVAs because of replicate sampling, replicate values of the same species from a region or sub-region were averaged and the average value used in ANOVAs

Dual stable isotope plots of sulfur versus carbon and nitrogen versus carbon for the plant sources of the Plum Island Sound estuary were used to examine sources of organic matter (Fig. 2). Typical isotopic ranges (depicted by boxes in Fig. 2) are included as a representation of the possible isotopic variation of plant sources in these analyses. Typical isotopic values were compiled from literature $\left(\delta^{13} \mathrm{C}\right.$ ranges: Fry \& Sherr 1984, Peterson \& Fry 1987, Currin et al. 1995: $\delta^{15} \mathrm{~N}$ ranges: Sigleo \& Macko 1985, Peterson \& Fry 1987, Sullivan \& Moncreiff 1990, Currin et al. 1995; $\delta^{34} \mathrm{~S}$ ranges: Peterson et al. 1985, Sullivan \& Moncreiff

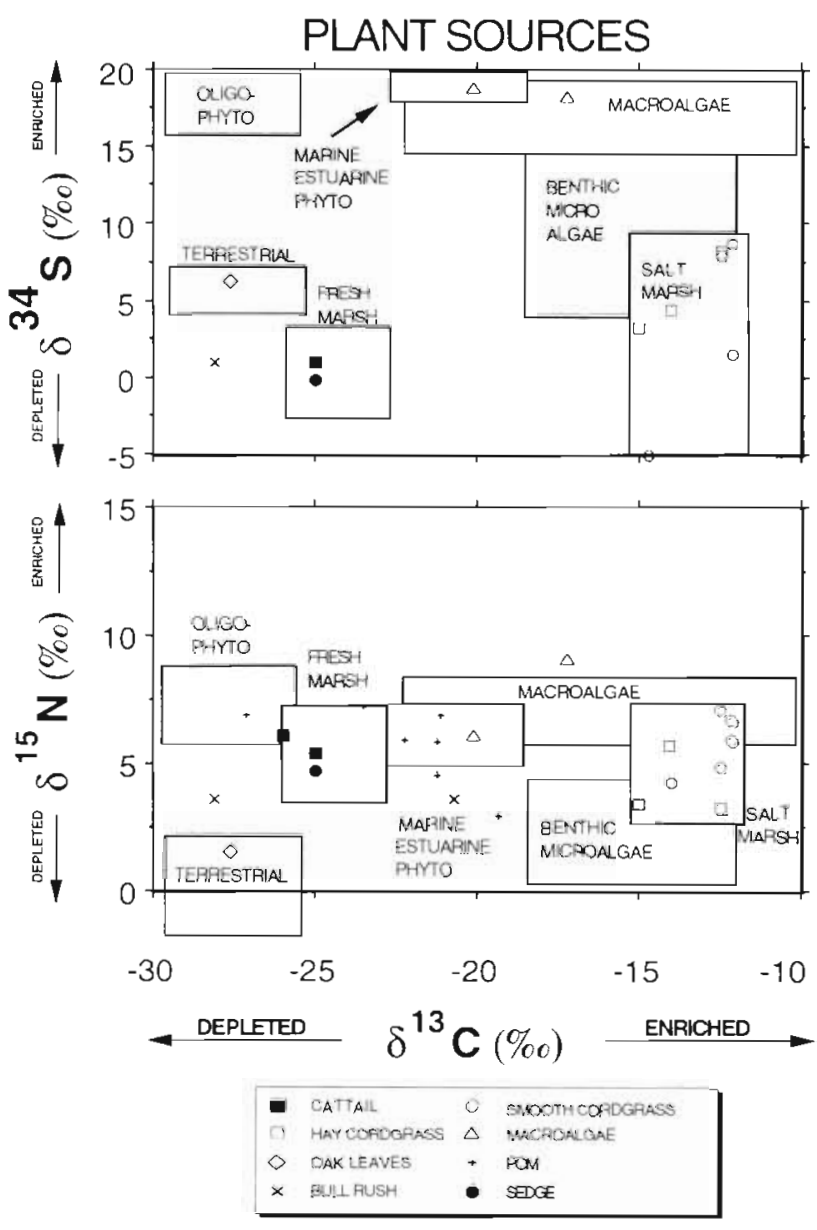

Fig. 2. $\delta^{34} \mathrm{~S}$ versus $\delta^{13} \mathrm{C}$ and $\delta^{15} \mathrm{~N}$ versus $\delta^{13} \mathrm{C}$ for plants throughout the Plum Island Sound estuary. Boxes represent typical ranges for plant sources (see text)

1990, Currin et al. 1995). The isotopic ranges help to provide estimates of isotopic values for some primary producers (phytoplankton and benthic microalgae) when it was either too difficult to get a clean enough sample or when there was insufficient sample material. These plots were used in conjunction with ANOVA and life-history information of individual species to infer food web relationships in the 3 regions of the estuary.

\section{RESULTS}

\section{Primary producers}

The $\mathrm{C}_{4}$ plants Spartina alterniflora and Spartina patens had an average $\delta^{13} \mathrm{C}$ value of $-13.9 \%$ with little variation $\left(-12.9\right.$ to $-15.8 \%$ ). In the upper estuary, $C_{3}$ fresh marsh plants were depleted compared with both Spartina species. The 2 dominant fresh marsh plants 
Typha latifolia and Scirpus americana had values of $-26.3 \%$ and $-28.9 \%$, respectively. Juncus effusus had a value of $-21.5 \%$ and Carex sp. had a value of $-25.8 \%$. Red oak Quercus rubra had a $\delta^{13} \mathrm{C}$ value of $-28.4 \%$. Macroalgae Enteromorpha sp. in the middle and lower estuary had $\delta^{13} \mathrm{C}$ values of -18.0 and $-20.9 \%$, respectively. Macroalgae (Cladophora sp., $-31.8 \%$ ) from the upper estuary were more depleted than the macroalgae of the middle and lower estuary. Sestonic POM composed of phytoplankton and suspended detritus had $\delta^{13} \mathrm{C}$ values ranging from $-27.9 \%$ in the upper estuary to -23.0 to $-20.1 \%$ in the middle estuary to $-21.9 \%$ in the lower estuary.

Stable nitrogen isotope ratios for estuarine primary producers varied between 1.3 and $8.8 \%$, with most values around 4 to $5 \%$. Emergent marsh plant $\delta^{15} \mathrm{~N}$ ranged from 3.2 to $6.8 \%$ with no apparent difference between $\mathrm{C}_{3}$ and $\mathrm{C}_{4}$ plants. $\delta^{15} \mathrm{~N}$ of macroalgae was between 5.8 and $8.8 \%$, while $\delta^{15} \mathrm{~N}$ values for POM ranged from a low of $2.7 \%$ in the middle estuary to a high of $6.7 \%$ in the upper and lower estuary. The value for red oak $(1.3 \%)$ was lower than the average value for all estuarine plants $(5.1 \pm 1.7 \%$ )

Stable sulfur isotope ratios of plants were more variable than those of carbon (Table 1) and reflected their different sources of sulfur. $\delta^{34} \mathrm{~S}$ values for primary producers varied from $+19.1 \%$ in macroalgae to $-5.1 \%$ for emergent marsh plants. The $\delta^{34} \mathrm{~S}$ for Spartina alterniflora varied the most, with ratios between -5.1 and $+9 \%$. Spartina patens was almost as variable as $S$. alterniflora, with values between +3.6 and $+8.4 \%$. Carex sp., Typha latifolia and Scirpus americana had low $\delta^{34} \mathrm{~S}$ values between +0.2 and $+1.4 \%$. The $\delta^{34} \mathrm{~S}$ of macroalgae ranged from +17.9 to $+19.1 \%$. Not enough material was obtained to measure $\delta^{34} \mathrm{~S}$ on the POM samples. Red oak had a $\delta^{34} \mathrm{~S}$ value of $+6.6 \%$ which is typical of terrestrial plants.

\section{Surficial sediments}

The $\delta^{13} \mathrm{C}$ value of $-22.9 \%$ for surface sediments in the upper estuary suggested a greater incorporation of depleted ${ }^{13} \mathrm{C}$ material compared to the middle estuary, which had heavier surface sediment $\delta^{13} \mathrm{C}$ values of -20.1 to $-19.4 \%$. Surface sediment $\delta^{15} \mathrm{~N}$ values were heaviest in the middle estuary at the Mid1 sub-region $(7.8 \%)$ and were lighter in the middle estuary at the Mid2 sub-region (3.1\%o) and in the upper estuary $(4.2 \%)$. Sediment samples were not analyzed for $\delta^{34} \mathrm{~S}$ as the signal would have been overwhelmed by reduced sulfur compounds and would not have been indicative of sedimented or benthic microalgal organic matter.

\section{Consumers}

The $\delta^{13} \mathrm{C}$ values of consumers indicated different mixes of organic matter sources were important in the different regions of the estuary (Tables $1 \& 2$ ). Consumer $\delta^{13} \mathrm{C}$ values were more depleted in the upper estuary $(-28.9$ to $-21.1 \%$ ) than the middle or lower estuary $(-23.4$ to $-15.3 \%$ ). Within a region, pelagic consumers had more depleted $\delta^{13} \mathrm{C}$ values than benthic consumers (Table 2).

Upper estuarine pelagic primary consumers, zooplankton and water boatmen, had $\delta^{13} \mathrm{C}$ values of -26.5 and $-25.2 \%$, respectively. The pelagic secondary consumers, three-spined sticklebacks, blueback herring and Atlantic silversides, had highly depleted $\delta^{13} \mathrm{C}$ values of between -28.9 and $-28.2 \%$. Amphipods, benthic primary consumers, had a $\delta^{13} \mathrm{C}$ value of $-24.3 \%$. The benthic secondary consumers, white perch, whitefingered mudcrabs, mummichogs, sand shrimp, American eel and winter flounder, had $\delta^{13} \mathrm{C}$ values between -24.7 and $-21.1 \%$. The bluegill $(-25.4 \%)$ had heavier $\delta^{13} \mathrm{C}$ values than the other pelagic secondary consumers, perhaps indicating that they consumed more of a mix of food from both the pelagic and benthic food webs than the other pelagic consumers.
Table 2. Two-way ANOVA and means for consumer $\delta^{13} \mathrm{C}$ and $\delta^{34} \mathrm{~S}$ values. Main factors were region (upper, middle, and lower estuary) and feeding zone (benthic or pelagic). " $p=0.01$. Means followed by the same superscript letter are not significantly different $(p<0.01$, Tukey test)

\begin{tabular}{|c|c|c|c|c|c|c|}
\hline ANOVA & $\mathrm{df}$ & $\begin{array}{l}\delta^{13} \mathrm{C} \\
\mathrm{MS}\end{array}$ & $F$ & $\mathrm{df}$ & $\begin{array}{l}\delta^{34} S \\
M S\end{array}$ & $F$ \\
\hline Region & 2 & 228.3 & $80.5^{\circ}$ & 2 & 22.7 & $6.5^{\circ}$ \\
\hline Feeding zone & 1 & 115.5 & $40.7^{\circ}$ & 1 & 65.8 & $18.9^{\circ}$ \\
\hline Region $\times$ Zone & 2 & 1.1 & 0.4 & 2 & 11.6 & 3.3 \\
\hline Residual & 41 & 2.8 & & 32 & 3.5 & \\
\hline Mean values & $\mathrm{n}$ & Mean & $\mathrm{SD}$ & $\mathrm{n}$ & Mean & SD \\
\hline \multicolumn{7}{|l|}{ Upper estuary } \\
\hline Benthic & 7 & $-23.3^{c}$ & 1.5 & 7 & $8.4^{c}$ & 1.5 \\
\hline Pelagic & 7 & $-26.4^{c}$ & 2.3 & 5 & $8.9^{\circ}$ & 2.2 \\
\hline \multicolumn{7}{|l|}{ Middle estuary } \\
\hline Benthic & 6 & $-16.2^{\mathrm{a}}$ & 0.6 & 5 & $7.0^{d}$ & 1.2 \\
\hline Pelagic & 14 & $-20.1^{b}$ & 1.9 & 11 & $10.8^{e}$ & 2.2 \\
\hline \multicolumn{7}{|l|}{ Lower estuary } \\
\hline Benthic & 6 & $-16.3^{a}$ & 0.5 & 4 & $9.3^{d}$ & 1.0 \\
\hline Pelagic & 7 & $-19.1^{b}$ & 1.8 & 6 & $13.4^{e}$ & 2.0 \\
\hline
\end{tabular}


Table 3. Two-way ANOVA and means for plant and consumer $\delta^{15} \mathrm{~N}$ values. Main factors are regions (upper, middle, and lower estuary) and trophic group (plant and primary, secondary, or tertiary consumers). $" p=0.01$

\begin{tabular}{|c|c|c|c|}
\hline ANOVA & df & $\begin{array}{l}\delta^{15} \mathrm{~N} \\
\mathrm{MS}\end{array}$ & $F$ \\
\hline Region & 2 & 1.5 & 0.8 \\
\hline Trophic group & 2 & 146.8 & $67.6^{\circ}$ \\
\hline Region $\times$ Trophic & 4 & 2.1 & 0.9 \\
\hline Residual & 53 & 2.2 & \\
\hline Mean values & $n$ & Mean & $\mathrm{SD}$ \\
\hline Plant & 18 & 5.0 & 1.8 \\
\hline Primary consumer & 15 & 7.8 & 0.9 \\
\hline Secondary consumer & 29 & 11.0 & 1.4 \\
\hline Tertiary consumer & 3 & 11.5 & 0.8 \\
\hline
\end{tabular}

The range of $\delta^{13} \mathrm{C}$ values for consumers in the middle $(-23.4$ to $-15.5 \%)$ and lower estuary $(-22.4$ to $-15.3 \%)$ were similar (Tables $1 \& 2$ ). Zooplankton $\delta^{13} \mathrm{C}$ values ranged from -23.3 to $-21.4 \%$. The range of $\delta^{13} \mathrm{C}$ for pelagic secondary consumers in the middle estuary $(-22.1$ to $-17.9 \%)$ was slightly shifted towards lighter values compared to the range for pelagic secondary consumers in the lower estuary $(-19.9$ to $-16.1 \%$ o). Nereis sp., a benthic deposit feeder and facultative suspension feeder, had a $\delta^{13} \mathrm{C}$ of $-17.0 \%$. Littorina saxatilis, which feeds on benthic diatoms and Spartina spp., had a $\delta^{13} \mathrm{C}$ of $-16.5 \%$. The range of $\delta^{13} \mathrm{C}$ for benthic secondary consumers in the middle $(-16.8$ to $-15.5 \%)$ and lower $(-17.8$ to $-15.3 \%$ o estuary were similar.

$\delta^{15} \mathrm{~N}$ values were correlated with trophic level rather than region within the estuary (Table 3 ). The range of $\delta^{15} \mathrm{~N}$ values for consumers $(6.2$ to $14.4 \%$ ) was almost identical across all sites (Table 1) and enriched compared to plant sources (Table 3, Fig. 3). Primary consumers had an average $\delta^{15} \mathrm{~N}$ value of $7.8 \%$ while secondary consumers averaged $11.0 \%$ and tertiary consumers averaged $11.5 \%$ (Table 3 ). An isotopic shift of $-+3 \%$ (Fig. 3) due to assimilation of nitrogen was observed between plants and primary consumers, and primary and secondary consumers; however, the trophic shift between secondary and tertiary consumers was less than $0.5 \%$. The low $\delta^{15} \mathrm{~N}$ value for tertiary consumers probably reflects a limited sample of tertiary consumers (bluefish only) as well as their consumption of a diverse spectrum of prey items from both the primary and secondary consumer groups.

The $\delta^{34} \mathrm{~S}$ values in consumers ranged from 5.3 to $15.4 \%$ across all habitats (Table 1 ). $\delta^{34} \mathrm{~S}$ values tended to be more enriched in the lower estuary ( 6.0 to $15.4 \%$ ) compared to the middle or upper estuary (5.3 to $13.9 \%$ ),

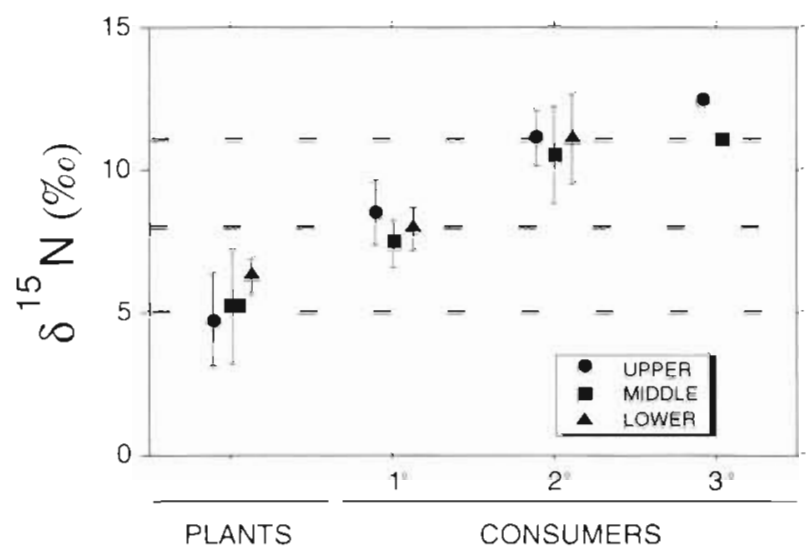

Fig. $3 . \delta^{15} \mathrm{~N}$ values (mean $\pm \mathrm{SD}$ ) for plants and primary, secondary, or tertiary consumers in the upper, middle and lower regions of Plum Island Sound estuary. Mean values among locations within a trophic level are not different while mean values among trophic levels are different (Table 3 )

probably due to greater seawater sulfate availability in the lower estuary. Within regions, $\delta^{34} \mathrm{~S}$ values were more enriched in pelagic consumers than benthic consumers, except in the upper estuary (Table 2). The upper estuary had the least variable distribution, with $\delta^{34} \mathrm{~S}$ values clustered around a mean of $8.6 \%$ (Tables $1 \& 2$ ).

\section{Multiple isotope comparisons}

\section{Middle and lower estuary}

The $\delta^{13} \mathrm{C}$ and $\delta^{34} \mathrm{~S}$ values for consumers in the middle and lower estuary are aligned between marine phytoplankton, benthic microalgae and Spartina spp. organic matter sources, with some influence of oligohaline phytoplankton in the middle estuary (Fig. 4). The combination of depleted $\delta^{13} \mathrm{C}$ values $(-22 \%)$ and slightly enriched $\delta^{34}$ S values $(+10 \%)$ in some pelagic consumers in the middle estuary may indicate the influence of oligohaline phytoplankton advected downstream.

Assuming the usual trophic enrichment $(+2$ to $+4 \%$ per trophic level) between consumers and their presumed food, the $\delta^{15} \mathrm{~N}$ values for primary consumers between 6 and $9 \%$, and for secondary consumers between 9 and $12 \%$, indicated use of estuarine-produced organic matter with a $\delta^{15} \mathrm{~N}$ value around $5 \%$ (Fig. 5). Zooplankton had $\delta^{15} \mathrm{~N}$ values that averaged $2.8 \%$ higher than POM. Atlantic silversides $(11.3 \%$ ) had average $\delta^{15} \mathrm{~N}$ values that were $3.3 \%$ higher than zooplankton.

Consumer $\delta^{34} \mathrm{~S}$ and $\delta^{13} \mathrm{C}$ isotope combinations indicated benthic and pelagic consumers tended to depend on different organic matter sources (Table 2 , Fig. 4). Benthic fauna had enriched $\delta^{13} \mathrm{C}$ and depleted 


\section{UPPER}
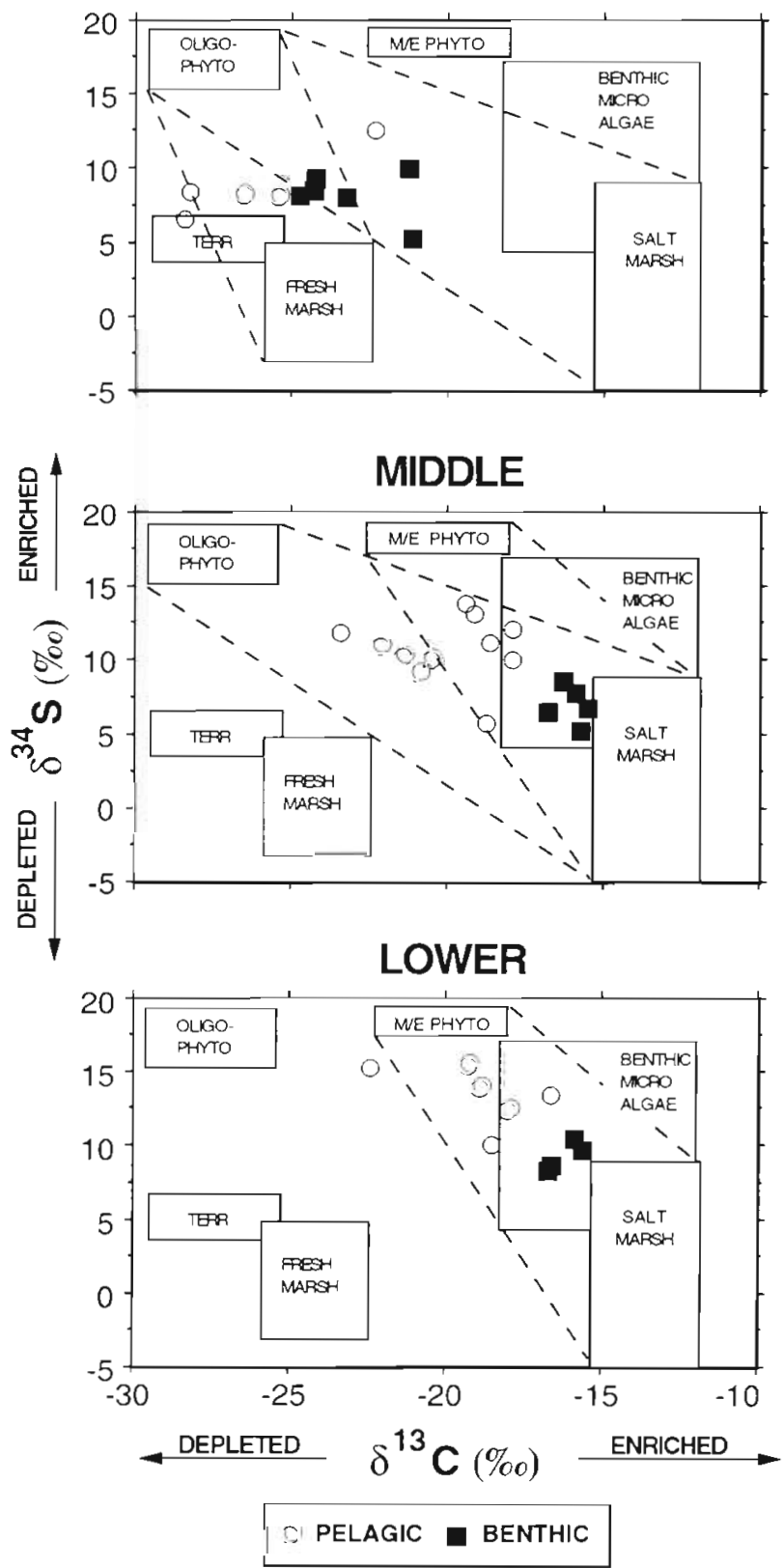

Fig. 4. $\delta^{34} \mathrm{~S}$ versus $\delta^{13} \mathrm{C}$ for pelagic and benthic consumer organisms in the upper, middle, and lower regions of Plum Island Sound estuary. Boxes represent typical ranges for plant sources (see text); macroalgae are not plotted because they are virtually non-existent in the estuary

$\delta^{34} \mathrm{~S}$ values, suggesting a greater reliance on Spartina spp. detritus and benthic microalgae compared to pelagic fauna, whose isotope combination indicated a greater reliance on phytoplankton (either marine or oligohaline). The combination of $\delta^{13} \mathrm{C}$ and $\delta^{15} \mathrm{~N}$ values in benthic and pelagic consumers also indicated terres-

\section{UPPER}
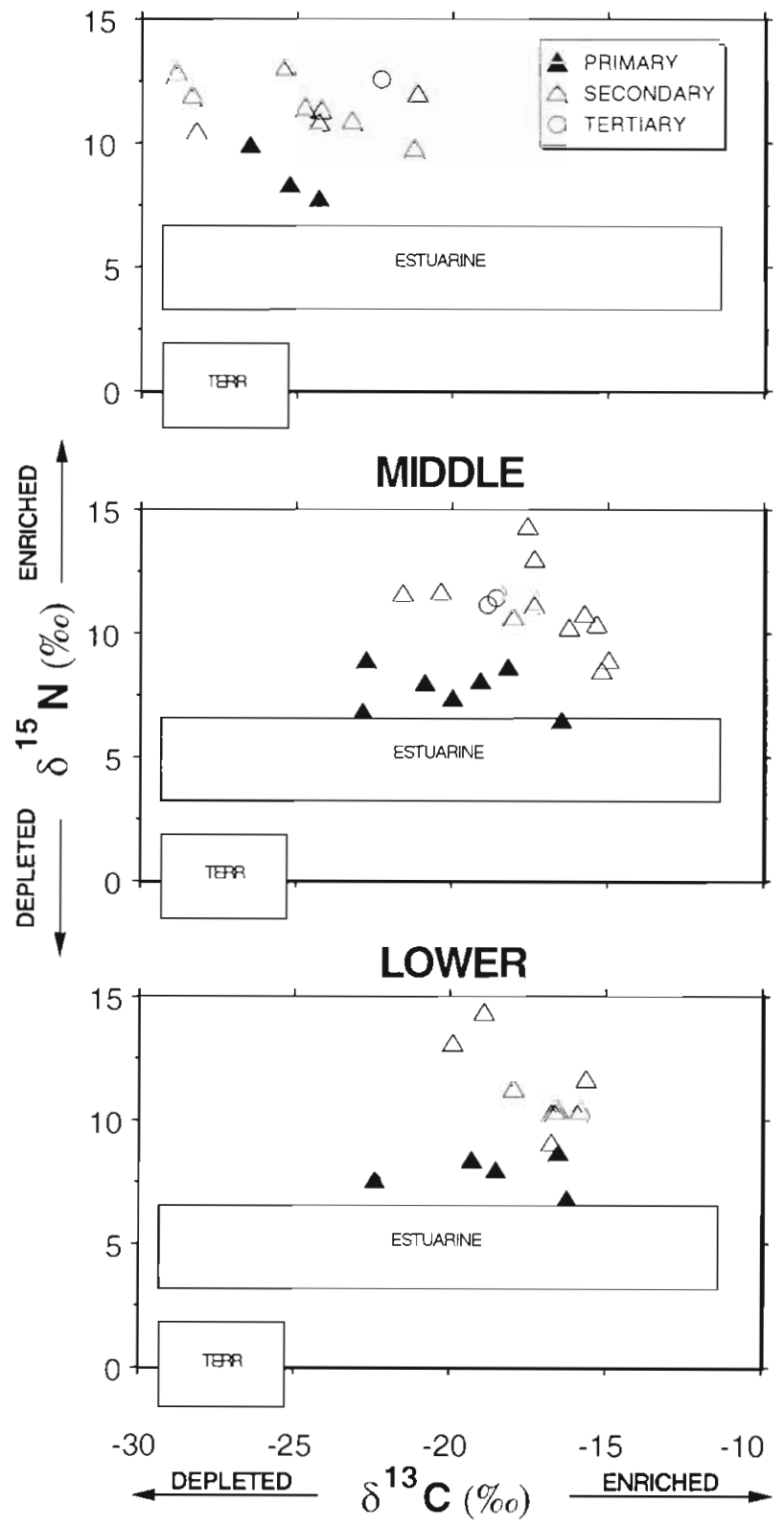

Fig. $5 . \delta^{15} \mathrm{~N}$ versus $\delta^{13} \mathrm{C}$ for primary, secondary, and tertiary consumer organisms in the upper, middle and lower regions of Plum Island Sound estuary. Boxes represent typical ranges for estuarine (fresh marsh, phytoplankton, benthic microalgae, and salt marsh) and terrestrially produced organic matter (see text)

trial organic matter was not important to consumers in the middle and lower estuary.

\section{Upper estuary}

The $\delta^{13} \mathrm{C}$ and $\delta^{34} \mathrm{~S}$ ratios of consumers in the upper estuary were arrayed between oligohaline phytoplank- 
ton, terrestrial organic matter, fresh marsh, Spartina spp. and benthic microalgae. Most organisms in the upper estuary had carbon isotope values between -29 and $-23 \%$ which indicated the use of oligohaline phytoplankton, fresh marsh or terrestrial organic matter (Fig, 4). Assuming the usual trophic enrichment (+2 to $+4 \%$ per trophic level) between consumers and their presumed food, the $\delta^{15} \mathrm{~N}$ ratios of the primary consumers indicated the use of organic matter sources with $\delta^{15} \mathrm{~N}$ values closer to $5 \%$ (estuarine sources) not $0 \%$ (terrestrial sources) (Fig. 5). Zooplankton had $\delta^{15} \mathrm{~N}$ values $(9.7 \%)$ that were $3 \%$ higher than the values for POM. Amphipods had $\delta^{15} \mathrm{~N}$ values $(7.6 \%)$ that were $2.1 \%$ higher than fresh marsh plants. The $\delta^{34} \mathrm{~S}$ values in consumers with $\delta^{13} \mathrm{C}$ isotope ratios between -29 and $-23 \%$ did not allow us to resolve that any POM source was dominant. All consumers had sulfur values around $+8 \%$, which could be derived from many different combinations of oligohaline phytoplankton, benthic microalgae, fresh marsh and terrestrial organic matter. A few organisms had carbon isotope values more enriched than $-23 \%$ (the lower expected value for fresh marsh), which indicated influence of either Spartina spp., benthic microalgae or marine phytoplankton. The depleted $\delta^{34} \mathrm{~S}$ values $(+5$ to $+8 \%$ ) and benthic feeding characteristics of these consumers suggested that Spartina spp. or benthic microalgae were the most probable organic matter sources (Fig, 4).

In contrast to the lower and middle estuary, isotopic values for $\delta^{34} \mathrm{~S}$ were less different among benthic and pelagic organisms in the upper estuary (Table 2, Fig. 4) but were different for $\delta^{13} \mathrm{C}$. The isotopic values for zooplankton were consistent with a mix of oligohaline phytoplankton and fresh marsh organic matter, assuming terrestrial organic matter is not important based on the $\delta^{15} \mathrm{~N}$ ratios. Benthic amphipods Gammarus tigrinus had isotope values very similar to zooplankton, although the heavier $\delta^{13} \mathrm{C}$ value indicated slightly more use of fresh marsh organic matter than zooplankton. Water boatmen, which are suspension feeders, fed on a mix of phytoplankton and suspended fresh marsh detritus.

Isotope values of consumers common to all regions

The isotopic values of organisms common to all 3 regions changed in a pattern consistent with predominant assimilation of locally produced organic matter (Fig. 6). The $\delta^{13} \mathrm{C}$ values for all species showed a strong shift towards lighter values in the oligohaline habitat compared to the middle estuary or lower estuary habitats. For example, the pelagic zooplanktivores (Atlantic silversides, sticklebacks and herring) all show a strong shift in their $\delta^{13} \mathrm{C}$ values from -18 to $-20 \%$ in
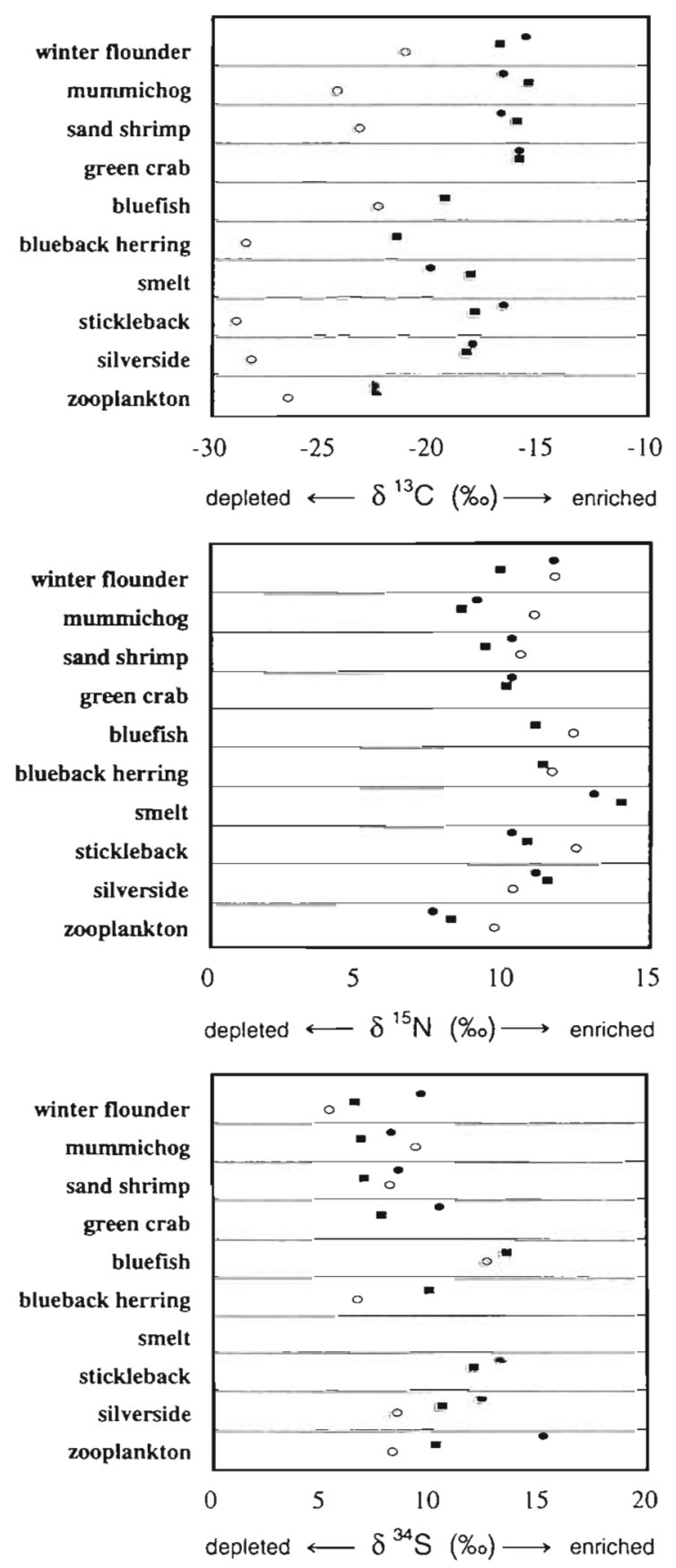

- Lower Estuary
- Middle Estuary
- Upper Estuary

Fig. $6 . \delta^{13} \mathrm{C}, \delta^{15} \mathrm{~N}$, and $\delta^{34} \mathrm{~S}$ plots of consumer organisms common to the upper, middle, and lower regions of Plum Island Sound estuary

the middle and lower estuary to -28 to $-30 \%$ in the upper estuary consistent with a change from marine to oligohaline phytoplankton as the base of the pelagic 
food web. The benthic feeders (winter flounder, mummichogs and sand shrimp) show a shift in their $\delta^{13} \mathrm{C}$ values from $-16 \%$ in the middle and lower estuary to -22 to $-24 \%$ in the upper estuary consistent with a change from Spartina spp. and benthic microalgae to fresh marsh as contributors to the base of the benthic food web. The pattern of $\delta^{15} \mathrm{~N}$ values indicated that broad relative trophic position (primary, secondary or tertiary consumer) is similar across all regions for individual species (Fig. 5). The $\delta^{34} \mathrm{~S}$ values change as expected along the tidally influenced gradient, with pelagic organisms from the middle and lower estuary usually having enriched $\delta^{34} \mathrm{~S}$ values compared to individuals of the same species from the upper estuary (Fig. 6).

\section{DISCUSSION}

Several of the patterns revealed by examination of organic matter sources for the food web of the Plum Island Sound estuary have implications for our general understanding of estuarine food webs. First, while there is substantial spatial heterogeneity in utilization of organic matter sources within a single estuary, consumers tend to use organic matter produced in the same region of the estuary in which they reside. Second, consumer dependence on terrestrially derived riverine organic matter is minimal, even in the relatively small region of the estuary where its availability is the highest. Third, benthic and pelagic organisms relied on different mixes of organic matter sources. Comparison of the stable isotopic composition of food webs among estuaries indicates that the relative importance of emergent salt marsh plant and algal organic matter may be influenced by hydrology.

\section{Importance of local sources of production}

Most primary producer $\delta^{13} \mathrm{C}, \delta^{15} \mathrm{~N}$, and $\delta^{34} \mathrm{~S}$ values (Table 1) were reasonably distinct and typical of the $\mathrm{C}_{3}$ and $\mathrm{C}_{4}$ plant groups which allowed us to use stable isotopes to infer organic matter use by consumers. For example, the $\delta^{13} \mathrm{C}$ of oak leaves was similar to other $\delta^{13} \mathrm{C}$ measures of terrestrial plants (Coffin et al. 1989, Peterson et al. 1994) and the $\delta^{15} \mathrm{~N}$ was distinctly lower than the average value for all estuarine plants, as expected. $\delta^{13} \mathrm{C}$ for phytoplankton (POM) varied across the estuary in a predictable manner based on $\delta^{13} \mathrm{C}$ DIC values and the approximately $-20 \%$ fractionation associated with $\mathrm{C}_{3}$ plant uptake of DIC (Fogel et al. 1992). $\delta^{13} \mathrm{C}$ DIC values ranged from -10 to $-15 \%$ in the upper estuary to near $0 \%$ at the lower estuary and offshore (Fry et al. 1992a, C. Hopkinson unpubl. data) and the $\delta^{13} \mathrm{C}$ of POM ranged from -27.9 to $-20.1 \%$. Fry et al. (1992a) estimated the $\delta^{13} \mathrm{C}$ value of phytoplankton in upper estuary to be about $-35 \%$ based on their contribution to the $\delta^{13} \mathrm{C}$ of the DOC pool. $\delta^{13} \mathrm{C}$ values for bulk POM measured in the present study are heavier than phytoplankton values estimated by Fry et al. (1992a), perhaps reflecting a detrital component to POM or differences in $\delta^{13} \mathrm{C}$ DIC between the years of sampling $\delta^{13} \mathrm{C}$ values of -30 to $-48 \%$ have been measured for freshwater phytoplankton (Rau 1978, LaZerte 1983). Reported measurements of estuarine phytoplankton have $\delta^{13} \mathrm{C}$ values between -22 and $-30 \%$ and $\delta^{13} \mathrm{C}$ values of $-22 \%$ are typical of marine phytoplankton (Matson \& Brinson 1990, Fogel et al. 1992). Although we were unable to measure the $\delta^{34} \mathrm{~S}$ of phytoplankton, we assumed it would have $\delta^{34} \mathrm{~S}$ values similar to macroalgae from the same region because both obtain their sulfur from seawater (Peterson \& Fry 1987, Michener \& Schell 1994). Unfortunately, we did not obtain enough material to measure the stable isotope composition of benthic microalgae. We infer the isotopic values for benthic microalgae from the literature (Sullivan \& Moncreiff 1990, Currin et al. 1995) and from a recent sampling (August 1996) in the upper estuary $\left(\delta^{13} \mathrm{C}\right.$, $-17.7 \%$, Jeffrey Hughes pers. comm.).

Consumers in all regions of the estuary relied most heavily on locally produced and available organic matter. Over the length of the estuary, the use and importance of organic matter gradually changed from oligohaline phytoplankton and fresh marsh organic matter in the upper estuary to oligohaline phytoplankton, benthic microalgae and salt marsh in middle estuary to marine phytoplankton, benthic microalgae and salt marsh in the lower estuary. Some downstream transport and use of oligohaline phytoplankton was apparent in the middle estuary and some transport and use of emergent salt marsh plant material was apparent in the lower estuary, Terrestrial organic matter was not evident in the food webs of the middle and lower estuary and was of minimal importance in the upper estuary.

Other studies have also noted the importance of local production to individual organisms. Peterson et al. (1985) observed that ribbed mussels in a salt marsh creek had isotopic ratios indicating use of salt marsh organic matter, while those nearer the mouth of the estuary used marine phytoplankton. Ruckelshaus et al. (1993) found that growth and $\delta^{13} \mathrm{C}$ values of blue mussels corresponded to differences in the abundance and $\delta^{13} \mathrm{C}$ values of local producers, suggesting that Padilla Bay, Washington, USA, mussels rely primarily on local sources of carbon for food. Examination of $\delta^{13} \mathrm{C}$ and $\delta^{15} \mathrm{~N}$ in biota from the Nanakita River estuary (Japan) revealed a strong marine primary production component for marine consumers in lower reaches of this watershed and contributions of vascular marsh plant 
material to suspension and surface deposit feeders (Wada et al. 1993)

The importance of fresh marsh and oligohaline phytoplankton to common estuarine species in the upper estuary was unexpected. The unique and consistent isotope values for common estuarine fishes in the upper estuary are an indication that fish move into this reach, grow and remain there during the summer season. Both fish and crustaceans have isotopic compositions that are relatively stable and modified mainly by growth (Tieszen et al. 1983, Hesslein et al. 1993). As a result, a migratory animal with slow growth may occupy an area for an extended period of time before the isotopic signature is altered. Conversely, a rapidly growing animal will quickly come into equilibrium with the new food sources. In a 2 yr survey of the abundance of fish and crustaceans across the estuary, we found that Atlantic silversides, sticklebacks, blueback herring, winter flounder, mummichogs, and sand shrimp all migrate into the oligohaline area in the spring (authors' unpubl. data). These species were captured in the oligohaline reach throughout the summer and individuals progressively increased in size, indicating either growth of a resident population or the immigration of larger individuals throughout the summer. The shift in isotope values of these organisms from those typical of higher salinity estuarine areas to those typical of the oligohaline reach indicate that they immigrate in the spring, remain, and grow in this area for the summer. Residence time in a particular habitat has been established for very few species (Fry 1981. Weinstein 1983, Weinstein \& O'Neil 1986, Deegan et al. 1990, Murphy 1991, Saucerman \& Deegan 1991). The isotopic values strongly imply the establishment of summer resident populations of winter flounder and mummichogs in the upper estuary similar to that which occurs in higher salinity regions (Butner \& Brattstrom 1960, Lotrich 1975, Saucerman \& Deegan 1991, Murphy 1991). The high growth rates and extended length of stay indicate the upper estuary serves as a juvenile rearing habitat for these species.

\section{Role of terrestrial organic matter in estuarine food webs}

Consumer dependence on riverine terrestrially derived organic matter is minimal in Plum Island Sound, even in the upper estuary where its availability is the highest. Assuming similar trophic level fractionation of ${ }^{15} \mathrm{~N}$ in the assimilation of terrestrial and estuarine salt marsh detritus, it appears that terrestrial organic matter is not an important source to higher trophic levels in the estuary. Our data on the trophic fractionation between zooplankton and POM of around $2 \%$ is close to that observed for zooplankton in other systems (Goering et al. 1990, Kling et al. 1992), indicating this was the most likely food source for these organisms. Similarly, the combination of $\mathrm{C}$ and $\mathrm{N}$ isotopes indicated little evidence that terrestrial organic matter contributes in any measurable way to the isotopic composition of consumers in the middle and lower estuary.

Complex food webs with several intermediate steps in the food chain between terrestrial organic matter and zooplankton are possible. If zooplankton were feeding on bacteria or microzooplankton, which can be expected to have higher $\delta^{15} \mathrm{~N}$ values than POM (Rau et al. 1983), then isotopic values of estuarine consumers may represent use of terrestrial organic matter. Assuming a standard trophic shift of $3 \%$ per trophic level, the difference between the $\delta^{15} \mathrm{~N}$ ratio of zooplankton $(\sim 10 \%)$ and terrestrial organic matter $(\sim 1 \%)$ represents a total fractionation of $9 \%$ or roughly 3 trophic levels. The few published measurements of bacterial $\delta^{13} \mathrm{C}$ or $\delta^{15} \mathrm{~N}$ available indicate that bacterial fractionation of organic carbon $(<1 \%$ ) and organic nitrogen ( 0 to $2 \%$ ) during decomposition of organic matter is small (Coffin et al. 1989, Coffin et al. 1994) but can be highly variable (Macko \& Estep 1984). The data available suggest that not enough fractionation occurs by the intermediate trophic steps to account for the observed $9 \%$ fractionation between zooplankton and terrestrial organic matter. If microorganisms degrading poor quality plant detritus (high C:N:S ratio) obtain their nitrogen from the water column (Tupas \& Koike 1990, Hoch et al. 1992, White \& Howes 1994), then predicting the $\delta^{15} \mathrm{~N}$ value for microbes requires an estimate of microbial fractionation during uptake of $\mathrm{NH}_{4}{ }^{+}$and the $\delta^{15} \mathrm{~N}$ value for $\mathrm{NH}_{4}{ }^{+}$. If the $\delta^{15} \mathrm{~N}$ value of DIN was near $5 \%$ (the midpoint of fresh and marine $\delta^{15} \mathrm{~N}$ for DIN; Coffin et al. 1994, Nadelhoffer \& Fry 1994 ) and fractionation was near $0 \%$ (as found in other estuaries at similar nutrient concentrations, Cifuentes et al. 1988, Hoch et al. 1992), then the predicted $\delta^{15} \mathrm{~N}$ values would be: terrestrial organic matter (1\%) $\rightarrow$ bacteria $(6 \%) \rightarrow$ microzooplankton $(9 \%$ ) $\rightarrow$ zooplankton $(12 \%) \rightarrow$ fish consumer $(15 \%)$. These predicted values for zooplankton and fish are about 1 trophic level higher than the measured values for Plum Island Sound organisms, indicating this is not the dominant pathway. This does, however, highlight the need for a better understanding of microbial and microzooplankton components of food webs.

The lack of an important role of terrestrial organic matter in the upper estuary food web was consistent with $\delta^{1.3} \mathrm{C}$ measures of bacteria and DOC in Plum Island Sound (Coffin et al. 1989, Fry et al. 1992a, Peterson et al. 1994). Peterson et al. (1994) suggested that bacterial populations in the upper estuary were responding to the inputs of highly labile material from 
the marsh and oligohaline phytoplankton, not inputs of low quality terrestrial organic matter. In addition, measurements of $\delta^{13} \mathrm{C}$ of bacteria from the upper estuary $(-11$ to $-17 \%)$ did not indicate a significant use of terrestrial organic matter (Coffin et al. 1989).

Several studies that examined the importance of riverine borne organic matter found this material was of minimal importance to higher trophic levels in estuaries (Incze et al. 1982, Simenstad \& Wissmar 1985, Conkright \& Sackett 1986, Bunn et al. 1989). Simenstad \& Wissmar (1985) found that terrestrially derived carbon was important to the food web only in the riverine portion of the estuary. Comparision of stable carbon isotope values for POC and filter feeding bivalves in Maine, USA, indicated use of terrestrial organic matter or phyto-detritus from an impounded lake in the upper estuary, but complete depencience on marine phytoplankton in the middle and lower estuary (Incze et al. 1982). Based on the isotopic ratios of a suite of organisms, Bunn et al. (1989) concluded that despite the large export of terrestrial organic matter by an Arctic river, terrestrial carbon did not make a significant contribution to the estuarine food web.

\section{Use of different organic matter sources by benthic and pelagic organisms}

We found that emergent marsh and benthic algal organic matter sources were more important to benthic organisms while phytoplankton was more important to pelagic organisms. Differences in isotopic values between pelagic and benthic consumers have been observed in other studies in marine systems (Fry \& Parker 1979, Fry et al. 1983, Simenstad \& Wissmar 1985, Peterson et al. 1986) but have been rarely evaluated systematically (Thomas \& Cahoon 1993, France 1995a). Similar to values observed in our study, depleted $\delta^{34}$ S values for benthic and enriched $\delta^{34} \mathrm{~S}$ values for pelagic fishes have been observed in offshore systems (Thomas \& Cahoon 1993), while enriched $\delta^{13} \mathrm{C}$ values for benthic fish and invertebrates compared to their pelagic equivalents have been documented for offshore coastal regions and seagrass meadows (France 1995a).

Although organisms tended to depend on different organic matter sources, there was clearly mixing between benthic and pelagic pathways. Links between benthic and pelagic food webs can occur in many ways. Higher trophic level consumers, such as Atlantic silversides and bluefish, often feed in both the pelagic and benthic regions. Many species found in zooplankton samples are resuspended benthic organisms that feed on detrital material (Heinle et al. 1977 , Roman 1984, Couch 1989). In addition, phytoplankton sedimentation and benthic algal and marsh detritus resuspension also contribute to the mixing of organic matter between the benthic and pelagic regions. This results in a continuum of consumer isotopic signatures with general tendencies between several particular organic matter sources rather than a tight clustering about a particular organic matter source.

\section{Comparison of emergent salt marsh and algal organic matter use among estuaries}

Comparison of the stable isotope composition of several estuarine food webs suggests that the high variability in the importance of vascular and algal organic matter (Schwinghammer et al. 1983, Jackson et al. 1986, Peterson et al. 1986, Sullivan \& Moncreiff 1990) is a result of the relative digestibility of these 2 sources and the physical control of estuarine circulation and productivity by hydrology, Salt marsh vascular plants are not as digestible as algal organic matter and a large proportion of this material is mineralized by microbes (Tenore \& Hanson 1980, Tenore 1983, Mann 1986, Newell \& Langdon 1986, Newman 1991j. Because of its higher digestibility, algal material is used in more direct and shorter food web paths to higher trophic levels (Mann 1986, Keller et al. 1990). Thus, if algae and salt marsh vascular plant production were of similar magnitude and equally available, we would expect algae to disproportionately contribute to the production of higher trophic levels.

The hydrology of estuaries, however, also influences the relative production and availability of producers. Increased tidal mixing decreases phytoplankton production (Monbet 1992), increases salt marsh vascular plant production (Steever et al. 1976) and increases transport of Spartina spp. detritus (Schwinghamer et al. 1983, Peterson et al. 1986, authors' pers. obs.). High tidal amplitude also favors the development of a diverse and abundant benthic animal community, many of which are detritivores (Warwick 1980, Wildish \& Peer 1983, Daborn 1986, Lopez 1988, Nixon 1988). Tidal inundation also allows motile organisms, such as small fish, crabs and shrimp access to the marsh surface for feeding (Weisburg \& Lotrich 1982, Rozas et al. 1988, Murphy 1991).

These studies suggest that the relative importance of algae and emergent salt marsh plants in food webs will vary with tidal amplitude. Essentially lentic conditions in low tidal amplitude estuaries favor the development and retention of in situ algal production and a food web more dependent on algal production. An example of an estuary with weak tidal influence, irregularly flooded marshes, moderate in situ algal productivity, and a food web dominated by algal organic matter is 
Graveline Bay Marsh (Mississippl, USA) in the Gulf of Mexico (Sullivan \& Moncreiff 1990). The Bay of Fundy (Nova Scotia, Canada) is an example of a macrotidal (10 m tidal amplitude) estuary with a food web dominated by benthic organisms and dependent on emergent salt marsh plants and benthic algae (Schwinghamer et al. 1983). Salt marsh estuaries with intermediate tidal ranges should have food webs which depend on a mix of algal and salt marsh organic matter. Examples of estuaries with intermediate tidal ranges and mixed food webs are Sapelo Island, Georgia (Peterson \& Howarth 1987), Newport River Port Marsh, North Carolina (Currin et al. 1995), Sippewissett Marsh, Massachusetts (Peterson et al. 1985, 1986), and Plum Island Sound, Massachusetts (this study).

The hypothesis that the use of algae and salt marsh organic matter is a product of lability and tidal mixing is, however, contrary to the suggestion that areas with larger areas of salt marsh should have food webs more dependent on salt marsh organic matter. This hypothesis suggests that large areas of marsh may be disconnected from aquatic estuarine food webs in low tidal amplitude systems because they are infrequently flooded. Tests of this hypothesis could be accomplished by systematically evaluating food webs using multiple stable isotopes in estuaries with a variety of tidal amplitudes and marsh and algal productivities.

Acknowledgements. We thank Charles Hopkinson, Anne Giblin, Bruce Peterson, Robert Holmes, Chris Neill, Joe Vallino, and Dixie Berthel for their comments on the manuscript. Kris Tholke, Jane Tucker, Todd Drummey, Joe Vallino, Ishi Buffam, Robert Buchsbaum, and a legion of volunteers helped with field collections. We thank Kris Tholke for completing the stable isotope analyses. This work was funded by NSF LMER grant OCE 9214461 and The Mellon Foundation.

\section{LITERATURE CITED}

Armstrong N (1982) Responses of Texas estuaries to freshwater inflows. In: Kennedy VS (ed) Estuarine comparisions. Academic Press, New York, p 103-120

Bunn SE, Barton DR, Hynes N, Power G, Pope MA (1989) Stable isotope analysis of carbon flow in a tundra river ecosystem. Can J Fish Aquat Sci 46:1769-1775

Butner A, Brattstrom BH (1960) Local movements in Menidia and Fundulus. Copeia 2:139-140

Cifuentes LA, Sharp JH, Fogel ML (1988) Stable carbon and nitrogen isotope biogeochemistry in the Delaware estuary. Limnol Oceanogr 33:1102-1115

Coffin RB, Cifuentes LA, Elderidge PM (1994) The use of stable carbon isotopes to study microbial processes in estuaries. In: Lajtha K, Michener RH (eds) Stable isotopes in ecology and environmental science. Blackwell Scientific Publications, London, p 222-240

Coffin RB, Fry B, Peterson BJ, Wright RT (1989) Carbon isotopic compositions of estuarine bacteria. Limnol Oceanogr 34:1305-1310

Conkright ME, Sackett WM (1986) A stable carbon isotope evaluation of the contribution of terriginous carbon to the marine food web in Bayboro Harbor, Tampa Bay, Florida. Contrib Mar Sci 29:131-139

Couch CA (1989) Carbon and nitrogen stable isotopes of meiobenthos and their food resources. Estuar Coast Shelf Sci 28:433-441

Currin CA, Newell SY, Paerl HW (1995) The role of standing dead Spartina alterniflora and benthic microalgae in salt marsh food webs: considerations based on multiple stable isotope analysis. Mar Ecol Prog Ser 121:99-116

Daborn GR (1986) Effects of tidal mixing on the plankton and benthos of estuarine regions of the Bay of Fundy. In: Bowman MJ, Yentsch CM, Peterson WT (eds) Tidal mixing and plankton dynamics. Springer Verlag, Berlin, p 390-413

Day JW Jr, Hall CAS, Kemp MW, Yanez-Arancibia A (1989) Estuarine ecology. John Wiley and Sons, New York

Deegan LA, Finn J, Hopkinson CS, Giblin AE, Peterson BJ, Fry $B$. Hobbie J (1995) Flow model analysis of the effects of organic matter-nutrient interactions on estuarine trophic dynamics. In: Dyer KR, Orth RJ (eds) Changes in fluxes in estuaries. Olsen and Olsen, Fredensborg, p 273-281

Deegan LA, Peterson BJ, Portier R (1990) Stable isotopes and cellulase activity as evidence for detritus as a food source for juvenile Gulf menhaden. Estuaries 13:14-19

Dornblaser M, Giblin AE. Fry B, Peterson BJ (1994) Effects of sulfate concentration in the overlying water on sulfate reduction and sulfur storage in lake sediments. Biogeochemistry (Dordr) 24:129-144

Fogel ML, Cifuentes LA, Velinsky DJ, Sharp JH (1992) Relationship of carbon availability in estuarine phytoplankton to isotopic composition. Mar Ecol Prog Ser 82:291-300

France RL (1995a) Carbon-13 enrichment in benthic compared to planktonic algae: foodweb implications. Mar Ecol Prog Ser 124:307-312

France RL (1995b) Nitrogen isotopic composition of marine and freshwater invertebrates. Mar Ecol Prog Ser 115: 205-207

Fry B (1981) Natural stable carbon isotope tag traces Texas shrimp migrations. Fish Bull US 79:337-345

Fry B, Brand W, Mersch FJ, Tholke K, Garritt R (1992b) Automated analysis system for coupled $\delta^{13} \mathrm{C}$ and $\delta^{15} \mathrm{~N}$. Anal Chem 64:288-291

Fry B, Hullar M, Peterson BJ, Saupe S, Wright RT (1992a) DOC production in a salt marsh estuary. Arch Hydrobiol Beih 37:1-8

Fry B, Parker PL (1979) Animal diet in Texas seagrass meadows: $\delta^{13} \mathrm{C}$ evidence for the importance of benthic plants. Estuar Coast Shelf Sci 8:499-509

Fry B, Scalan RS, Parker PL $(1983){ }^{13} \mathrm{C} /{ }^{12} \mathrm{C}$ ratios in marine food webs of the Torres Strait, Queensland. Aust J Mar Freshwat Res 34:707-715

Fry B, Sherr EB (1984) $\delta^{13} \mathrm{C}$ Measurements as indicators of carbon flow in marine and freshwater ecosystems. Contrib Mar Sci 27:13-47

Gearing JN (1988) The use of stable isotope ratios for tracing the nearshore-offshore exchange of organic matter. In: Jansson BO (ed) Lecture notes on coastal and estuarine studies, coastal offshore ecosystem interactions. SpringerVerlag, Berlin, p 69-101

Goericke R, Montoya JP, Fry B (1994) Physiology of isotopic fractionation in algae and cyanobacteria. In: Lajtha K, Michener RH (eds) Stable isotopes in ecology and environmental science. Blackwell Scientific Publications, London, p 187-221

Goering JV, Alexander V, Haubenstock N (1990) Seasonal variability of stable carbon and nitrogen isotope ratios of organisms in North Pacific Bay. Estuar Coast Mar Sci 30 : $239-260$ 
Hackney CT, Hames EB (1980) Stable carbon isotope composition of fauna and organic matter collected in a Mississippi estuary. Estuar Coast Shelf Sci 10:703-708

Heinle DR, Harris RP, Urtach JF, Flemer DA (1977) Detritus as food for estuarine copepods. Mar Biol 40:341-353

Hesslein RH, Hallard A, Ramlal P (1993) Replacement of sulfur, carbon, and nitrogen in tissue of growing broad whitefish (Coregonus nasus) in response to a change in diet traced by delta s-34, delta $\mathrm{c}-13$ and delta n-15. Can J Fish Aquat Sci 50:2071-2076

Hoch MP, Fogel ML, Kirchman DL (1992) Isotope fractionation associated with ammonium uptake by a marine bacterium. Limnol Oceanogr 37:1447-1459

Incze LS, Mayer LM, Sherr EB, Macko SA (1982) Carbon inputs to bivalve mollusks: a comparison of two estuaries. Can J Fish Aquat Sci 39:1348-1352

Ittekkot V (1988) Global trends in the nature of organic matter in river suspensions. Nature 332:436-438

Jackson D, Harkness DD, Mason CF, Long SP (1986) Spartina anglica as a carbon source for salt-marsh invertebrates: a study using $\delta^{13} \mathrm{C}$ values. Oikos 46:163-170

Jerome WC Jr, Chesmore AP, Anderson CO Jr (1968) A study of the marine resources of the Parker River-Plum Island Sound estuary. Mass Dept of Nat Resour Div Mar Fish Monograph Ser No. 6, p 1-79

Keller PD, Kelly S, Sullivan B (1990) Growth of juvenile Atlantic menhaden, Brevoortia tyranus in MERL mesocosms: effects of eutrophication. Limnol Oceanogr 35 : $109-122$

Kling GW, Fry B, O'Brien WJ (1992) Stable isotopes and planktonic trophic structure in arctic lakes. Ecology 73:561-566

Lajtha K, Marshall JD (1994) Sources of variation in the stable isotopic composition of plants. In: Lajtha K. Michener RH (eds) Stable isotopes in ecology and environmental science. Blackwell Scientific Publications, London, p 1-21

LaZerte BD (1983) Stable carbon isotope ratios: implications for the source of sediment carbon and for phytoplankton carbon assimilation in Lake Memphremagog, Quebec. Can J Fish Aquat Sci 40:1658-1666

Lopez GR (1988) Comparative ecology of macrofauna of freshwater and marine muds. Limnol Oceangr 33:946-962

Lotrich VA (1975) Summer home range and movements of Fundulus heteroclitus (Pisces: Cyprinodontidae) in a tidal creek. Ecology 56:191-198

Maberly SC, Raven JA, Johnston AM (1992) Discrimination between ${ }^{12} \mathrm{C}$ and ${ }^{13} \mathrm{C}$ by marine plants. Oecologia 91 : $481-492$

Macko SA, Estep MLF (1984) Microbial alteration of stable nitrogen and carbon isotope compositions of organic matter. Org Geochem 6:787-790

Mallin $M$, Paerl H (1994) Planktonic trophic transfer in an estuary: seasonal diel and community effects. Ecology $75(8): 2168-2184$

Mann KH (1986) The role of detritus at the land-sea boundary. In: Lasserre P. Martin JM (eds) Biogeochemical processes at the land-sea boundary. Elsevier, Amsterdam, p $123-140$

Matson EA, Brinson MM (1990) Stable carbon isotopes and the C:N ratio in the estuaries of the Pamlico and Neuse Rivers, North Carolina. Limnol Oceanogr 35(6):1290-1300

Michener RH, Schell DM (1994) Stable isotope ratios as tracers in marine aquatic food webs. In: Lajtha K, Michener RH (eds) Stable isotopes in ecology and environmental science. Blackwell Scientific Publications, London, p 138-157

Minagawa M, Wada E (1984) Stepwise enrichment of ${ }^{15} \mathrm{~N}$ along food chains: further evidence and the relation between $\delta^{15} \mathrm{~N}$ and animal age. Geochim Cosmochim Acta 48:1135-1140

Monbet Y (1992) Control of phytoplankton biomass in estuaries: a composition analysis of microtidal and macrotidal estuaries. Estuaries 15:563-571

Montagna P, Ruber E (1980) Decomposition of S. alterniflora in different seasons and habitats of a northern Massachusetts salt marsh and a comparison with other regions. Estuaries 56:1859-1861

Murphy SC (1991) The ecology of estuarine fishes in southern Maine high salt marshes; access corridors and movement patterns. MSc thesis, University of Massachusetts, Amherst

Nadelhoffer KJ, Fry B (1994) Nitrogen isotope studies in forest ecosystems. In: Lajtha K, Michener RH (eds) Stable isotopes in ecology and environmental science. Blackwell Scientific Publications, London, p 22-44

Newell RIE, Langdon CJ (1986) Digestion and absorption of refractory carbon from the plant Spartina alterniflora by the oyster Crassostrea virginica. Mar Ecol Prog Ser 34: $105-115$

Newell RIE, Marshall N, Sasekumar A, Chong VC (1995) Relative importance of benthic microalgae, phytoplankton, and mangroves as sources of nutrition for penaid prawns and other coastal invertebrates from Malaysia. Mar Biol 123:595-606

Newman RM (1991) Herbivory and detritivory on freshwater macrophytes by invertebrates: a review. J North Am Benthol Soc 10:89-114

Nixon SW (1988) Physical energy inputs and the comparative ecology of lake and marine ecosystems. Limnol Oceanogr 33:1005-1025

Nixon SW, Oviatt CA, Frithsen J, Sullivan B (1986) Nutrients and the productivity of estuarine and coastal marine ecosystems. J Limnol Soc South Afr 12(1/2):43-71

Peterson BJ, Fry B (1987) Stable isotopes in ecosystem studies. Annu Rev Ecol Syst 18:293-320

Peterson BJ, Fry B, Hullar M, Saupe S, Wright R (1994) The distribution and stable carbon isotopic composition of dissolved organic carbon in estuaries. Estuaries 17:111-121

Peterson BJ, Howarth RW (1987) Sulfur, carbon, and nitrogen isotopes used to trace organic matter flow in the saltmarsh estuaries of Sapelo Island, Georgia. Limnol Oceanogr 32:1195-1213

Peterson BJ, Howarth RW, Garritt RH (1985) Multiple stable isotopes used to trace the flow of organic matter in estuarine food webs. Science 227:1361-1363

Peterson BJ, Howarth RW, Garritt RH (1986) Sulfur and carbon isotopes as tracers of salt-marsh organic matter flow. Ecology 67:865-874

Peterson BJ, Howarth RW, Lipschultz F, Ashendorf D (1980) Salt marsh detritus: an alternative interpretation of stable carbon isotope ratios and the fate of Spartina alterniflora. Oikos 34:173-177

Rau G (1978) Carbon-13 depletion in a subalpine lake: carbon flow implications. Science 201:901-902

Rau GH, Mearns AJ, Young DR, Olson RJ, Schafer HA, Kaplan IR (1983) Animal ${ }^{13} \mathrm{C} /{ }^{12} \mathrm{C}$ correlates with trophic level in pelagic food webs. Ecology 64:1314-1318

Roman MR (1984) Utilization of detritus by the copepod, Acartia tonsa. Limnol Oceanogr 29(5):949-959

Rozas LP, McIvor CC, Odum WE (1988) Intertidal rivulets and creek banks: corridors between tidal creeks and marshes Mar Ecol Prog Ser 47:303-307

Ruckelshaus MH, Wissmar RC, Simenstad CA (1993) The importance of autotroph distribution to mussel growth in a well-mixed, temperate estuary. Estuaries 16:898-912 
Ryther JH (1969) Photosynthesis and fish production in the sea. Science 166:72-76

Saucerman SE, Deegan LA (1991) Lateral and cross-channel movement of young-of-the-year winter flounder (Pseudopleuronectes americanus) in Waquoit Bay, Massachusetts. Estuaries 14(4):440-446

Schoeninger MJ, DeNiro MJ (1984) Nitrogen and carbon isotopic composition of bone collagen from marine and terrestrial animals. Geochim Cosmochim Acta 48:625-639

Schwinghamer P, Tan FC. Gordon DC Jr (1983) Stable carbon isotope studies on the Pecks Cove mudflat ecosystem in the Cumberland Basin, Bay of Fundy. Can J Fish Aquat Sci 40 (Suppl 1):262-272

Sigleo AC, Macko SA (1985) Stable isotope and amino acid composition of estuarine dissolved colloidal material. In: Sigleo AC. Hattori A (eds) Marine and estuarine geochemistry. Lewis Publishers, Inc, Chelsea, MI, p 29-46

Simenstad CA, Wissmar RC $(1985) \delta^{13} \mathrm{C}$ evidence of the origins and fates of organic carbon in estuarine and nearshore food webs. Mar Ecol Prog Ser 22:141-152

Steever EZ, Warren RS, Wiering WA (1976) Tidal energy subsidy and standing crop production of Spartina alterniflora. Estuar Coast Mar Sci 4:473-478

Sullivan MJ, Moncreiff CA (1990) Edaphic algae are an important component of salt marsh food-webs: evidence from multiple stable isotope analyses. Mar Ecol Prog Ser 62:149-159

Tenore KR (1983) What controls the availability to animals of detritus derived from vascular plants: organic nitrogen enrichment or caloric availability. Mar Ecol Prog Ser 10: 307-309

Tenore KR, Hanson RB (1980) Availability of detritus of different types and ages to a polychaete macroconsumer Capitella capitata. Limnol Oceanogr 25:553-558

Thomas CJ, Cahoon LB (1993) Stable isotope analyses differentiate between different trophic pathways supporting rocky-reef fishes. Mar Ecol Prog Ser 95:19-24

Tieszen LL, Boutton TW, Tesdahl KG, Slade NA (1983) Frac-

This article was presented by B. \& E. Sherr (Senior Editorial Advisors), Corvallis, Oregon, USA tionation and turnover of stable carbon isotopes in anima tissues: implications for $\delta^{13} \mathrm{C}$ analysis of diet. Oecologia 57 $32-37$

Tupas L, Koike I (1990) Amino acid and ammonium utilization by heterotrophic marine bacteria grown in enriched seawater. Limnol Oceanogr 35:1145-1155

Vorosmarty CJ, Loder TC III (1994) Spring-near tidal contrasts and nutrient dynamics in marsh-dominated estuaries: the spectrum effect. Estuaries 17:537-551

Wada E, Kabaya Y, Kurihara Y (1993) Stable isotopic structure of aquatic ecosystems. J Biosci (Bangalore) 18:483-499

Warwick RM (1980) Population dynamics and secondary production of benthos. In: Tenore $K$, Coull $B$ (eds) Marine benthic dynamics. Univ South Carolina Press, Columbia p 1-24

Weinstein MP (1983) Population dynamics of an estuarinedependent fish, the spot (Leiostomus xanthurus), along a tidal-creek-seagrass meadow coenocline. Can J Fish Aquat Sci 40:1633-1638

Weinstein MP, O'Neil SP (1986) Exchange of marked juvenile spots between adjacent tidal creeks in the York River estuary, Virginia. Trans Am Fish Soc 115:93-97

Weisberg SB, Lotrich VA. (1982) The importance of an infrequently flooded intertidal marsh surface as an energy source for the mummichog: an experimental approach. Mar Biol 66:307-310

White DS, Howes BL (1994) Long-term ${ }^{15} \mathrm{~N}$-nitrogen retention in the vegetated sediments of a New England salt marsh. Limnol Oceanogr 39(8):1878-1892

Wildish DJ, Peer D (1983) Tidal current speed and production of benthic macrofauna in the lower Bay of Fundy. Can J Fish Aquat Sci 40:309-321

Wright RT, Coffin RB, Lebo ME (1987) Dynamics of planktonic bacteria and heterotrophic microflagellates in the Parker River, northern Massachusetts. Cont Shelf Res 7 : $1383-1397$

Zar JH (1984) Biostatistical analysis, 2nd edn. Prentice-Hall Inc, Englewood Cliffs, NJ

Manuscript first received: February 12, 1996

Revised version accepted: November 22, 1996 